Chapter 5

\title{
Employer strategies and the fragmentation of local employment: the case of contracting out local authority services
}

\author{
Suzanne Reimer
}

\section{Introduction}

The primary focus of the chapter is upon the ways in which employers structure and influence local labour market dynamics. Whilst my arguments draw upon a specific study of the former Conservative government's policy of compulsory competitive tendering (CCT) for manual work within UK local authorities, a central aim is to address a number of broader issues surrounding the conceptualisation of local labour markets. The consideration of this particular group of workers and their employers, however, is not insignificant: as private sector cleaning and catering firms became increasingly involved in local government contracting through the early 1990s, firms' employment strategies increasingly began to transform the nature of local labour markets, reshaping the experiences of low paid workers in particular places. Elsewhere, I have considered labour market transformations from the perspective of employees (Reimer, 1998; Reimer, 1999a): here my attention primarily is directed to the activities of employers.

Since the late 1980s there not only has been a growing interest in the nature, performance and regulation of local labour markets, but also most discussants concur that an interest in local labour market dynamics now has supplanted considerations of local labour market 'cartography' (Martin, 2000; Peck 1996; Coe, 2000). Nonetheless, theoretical perspectives on labour markets remain relatively underdeveloped. We not only need to "add empirical weight to the argument that [labour] markets are, by their very nature, inherently 'local'” (Coe, 2000, 79, emphasis mine), but also must pursue the implications of current labour market 
processes (such as the deepening and recomposition of labour market inequalities) for the conceptual frameworks we use. The chapter begins with a review of the ways in which local labour markets have been conceptualised. Following a brief sketch of the particular local authorities used as case studies, the chapter then focuses upon the ways in which cleaning and catering firms have shaped, and been shaped by, different local labour market contexts. In the light of this discussion, the concluding section then returns to some broader analytical questions.

\section{The Concept of a Local Labour Market}

Theorising the processes at work in local labour markets is notoriously difficult (Cooke, 1983; Pinch, 1987; Peck, 1989a; Morrison, 1990; Peck , 1992). The term 'local labour market' has often been used in an ambiguous way, to refer "to any number of subnational boundaries” (Morrison, 1990, 498). Morrison (1990) has argued that conceptual difficulties have arisen in part because the notion originally derived from discussions within economics. ${ }^{1}$ The notion of the 'local' labour market was used by economists to control for 'extraneous' factors affecting wage dispersion and was defined in terms of the location of an employing establishment or group of establishments which shaped hiring and wage policies (Morrison, 1990,). Labour economists, therefore, assumed that there were general processes at work, and sought a 'laboratory' in which to observe these general processes: a particular local labour market would control for national or regional differences (ibid.). Further, "it did not really matter whether the laboratory was Detroit or Boston, Chicago or New York": the individual local labour market used for study was incidental to the analysis. (ibid., 500-502). Yet for geographers, clearly, the idea of a local labour market is interesting precisely because labour markets are not the same. Not surprinsgly, problems arise when trying to use concepts designed to eschew difefrence in order tohoghlight difference. As a result, it has been difficult for geographers to make comparisons

\footnotetext{
${ }^{1}$ Cf. Fischer and Nijimkamp's $(1987,37)$ point that that the theories utilised in the study of local labour markets "were developed for economic rather than geographic space”; see also Martin (1986).
} 
between local processes without allowing the labour market to be defined in terms of local conditions.

Most empirical studies of local labour markets in geography have been based on upon delimiting travel-to-work areas, or assessing local job search strategies, frequently in a largely technical way. ${ }^{2}$ While attempting to draw fixed boundaries around travel-to-work areas creates one set of difficulties, there is also a theoretical problem inherent in the use of such a strategy: it assumes that space is a container, "within which a set of generalised processes operate, largely unaffected by their spatial context.” (Peck, 1989a, 44). Further, Peck contends that the use of the travelto-work area does not assist in the conceptualisation of the relationship between space and labour market segmentation. We must account for the ways in which divisions of gender, ethnicity, and skill, for example, will shape different local labour markets for different groups of people. Peck's argument is that labour market segmentation acts to “'slice up' local labour markets, undermining their internal coherence to a potentially debilitating degree," and he therefore turns to look at the ways in which labour markets might be segmented in locally-specific ways (Peck, 1989a, 49).

Hanson and Pratt (1995, 13-14) have taken issue with Peck’s account. They suggest that he

possibly overstates the 'debilitating' incoherence of local labour markets by ignoring the spatial fragmentation of employment within metropolitan labour markets, which may entail the clustering of jobs from different occupational segments.

Although Hanson and Pratt acknowledge that labour market segmentation does occasionally render local labour markets inchoate, their research demonstrates that “distinctive labour markets and employment niches” can develop within a city, such that “a sharp spatial segregation... mirrors labour market segmentation.” $(1995,162)$.

However, the debate can be taken further. It is the reliance upon labour market segmentation theory itself which poses difficulties for the conceptualisation of

\footnotetext{
${ }^{2}$ On job search theory, see Clark, (1987). In the UK, the Department of Employment's official definition of local labour market areas as travel-to-work areas has undoubtedly structured much research. See, for example, Coombes et al. (1985); Hubbuck and Coombes (1989).
} 
local labour markets. There are two issues at stake. First, Peck's work in particular implies that structures of segmentation fall, pre-formed, upon local labour markets. He argues, for example, that "the notion of the local labour market can be deployed as a mid-level theoretical device in order to specify and understand the ways in which different segmentation processes intersect and are differentially reconciled at the local scale” (Peck, 1996, 96, emphasis mine). This rather problematically suggests that labour market segments can somehow emerge 'outside' space and place-even if, as Peck claims, it is possible to evaluate the specific local dimensions of segmentation.

In some ways, this critique resonates with that in Pratt's (1999) recent account of the 'discursive geographies' at work in labour markets. Pratt $(1999,216)$ argues that whilst an emphasis on 'middle range' theorising "helpfully highlights the contingency and variability of social and economic processes,” such a stance posits "the social and cultural processes that lead to the marginalisation of certain groups in the labour market as empirical rather than theoretical puzzles.” Rather than pursuing a 'middle way', Pratt $(1999,217)$ draws upon poststructuralist theories of discourse and the subject to address the ways in which "material inequalities are produced through everyday situated practices.” My discussion here is not an explicitly poststructuralist account, although I would draw attention to the ways in which discursive constructions by employers (such as appropriate home-work distances for working women with children) do mesh with hiring practices, for example. Rather, the chapter directs attention to the potential difficulty involved in keeping the theoretical 'work' of concepts such as segmentation and regulation at a separate level from the notion of the local labour market.

A second problem with closely adopting the conceptual apparatus of labour market segmentation theory (even its 'fourth generation' variant) ${ }^{3}$ is that it leaves us ill-equipped to grapple with the diverse employment structures which have emerged at the end of the twentieth century (and which are evident in the example of

\footnotetext{
3 See Peck (1996, 111-112),, Table 4.1.
} 
compulsory competitive tendering discussed below). Segmentation theory was originally developed as a means of explaining divisions between primary and secondary, internal and external labour markets (see Peck, 1989b). In the primary sector, white, prime-age men benefited from stable career ladders, while 'other' social groups (including women, ethnic minorities, older and disabled workers) were confined to the inherently insecure secondary sector. In the current era, it is more problematic to theorise divisions between workers in such a 'horizontal' fashion. Rather, focusing upon the fragmentation of work in local labour markets provides a more appropriate means of viewing the increasingly heterogeneous ways in which jobs are arranged, and employees positioned. ${ }^{4}$ Workers are now divided, one from another, in a strongly 'vertical' manner.

My focus below upon the contracting-out of manual work in local government is obviously a very particular one: the dynamics of the tendering process, the operation of contracts, or indeed firms' withdrawal from contracts are relatively distinctive. However, the outcomes of compulsory competitive tendering (CCT) provide a useful window on two highly gender-segregated and marginalised sectors of employment — the 'bottom end' of the labour market—and the chapter illuminates the ways in which these particular types of employment opportunities are constructed in space and place.

\section{Three local labour markets}

The case study local authorities of Cambridgeshire, Camden and County Durham represent a range of different factors influencing compulsory competitive tendering (CCT), including the nature of employment change in each authority and the processes by which private firms made decisions to bid for particular contracts. ${ }^{5}$ A distinct political contrast was evident, particularly between the two county councils. Whilst Durham has long been under Labour control, Cambridgeshire was

\footnotetext{
4 The term 'fragmented polarisation' is taken from Mingione (1991). See the critique and extension of Mingione's work contained within Reimer (1999a).

${ }^{5}$. This section draws directly upon the discussion in Reimer (1999a, 162-166), although the latter includes further details of changing wage rates and terms and conditions of work as CCT proceeded.
} 
Conservative-controlled during the early 1980s—at which time they contracted out building cleaning work voluntarily. The London Borough of Camden has also had a long history of Labour control. All three authorities had embarked upon a second 'round' of tendering (a three to four year cycle) during the period in which the research was conducted.

Cambridgeshire has always been a predominantly rural county. Despite a degree of commercial and industrial development in Cambridge and Peterborough (including the much heralded expansion of high technology industry on science parks surrounding Cambridge), a strong agricultural legacy remains (Crang and Martin, 1991; SQP, 1985). The importance of the agricultural sector to the local economy has had considerable implications for women's employment opportunities, particularly in Fenland villages (McDowell and Massey, 1984). In 1991, just over 3\% of the Cambridgeshire population was employed in agriculture (compared with 1.95\% nationally); in the East Cambridgeshire and Fenland areas, the figures were $7.35 \%$ and 6.52\% respectively (OPCS, 1991). For many women, working as a cleaner, or in the kitchen at a local school, provided one of the few alternatives to back-breaking work on the land. The scattered villages and hamlets in the county have never been well linked by public transport, and so spatial constraints are significant, and this was not helped by the deregulation of bus services in 1986, which led both to fare increases and to a decrease in frequency of service.

Gender divisions of labour within County Durham have been radically reworked during the post-war period. Declining male employment in the coal industry occurred alongside the expansion of manufacturing work for women in the late 1960s and 1970s (McDowell and Massey, 1984; Hudson, 1989; Hudson et al., 1992). More recently, manufacturing decline, particularly within the clothing sector, has had substantial implications for households which were dependent upon a sole female breadwinner. Jobs within the private service sector were very poorly paid, whilst the public sector has provided one of the few relatively stable employment opportunities, particularly for women. Like Cambridgeshire, County Durham is also 
characterised by a scattered settlement pattern. However, public transportation links between towns and villages are reasonably good: although fares are not inexpensive, services are regular.

Camden's local labour market context differs substantially from the other two areas. Whereas the large county council areas of Cambridgeshire and Durham consist of a series of (sometimes overlapping) local labour markets, Camden is much smaller in geographical extent, and is characterised by considerable daily inflows and outlfows of labour. Job opportunities within the local manufacturing sector have declined significantly since the 1970s, leaving few alternatives to low paid, service sector employment. A decline in blue collar working in both the railways and in local government itself has been particularly evident (Goodwin et al., 1993). Low pay has always been a feature of private service sector employment in Camden, as elsewhere in London (Sassen, 1991). However, low pay levels became increasingly characteristic of public sector employment as CCT progressed. During the 1980s, council employees were protected from low wages through a "Minimum Earnings Guarantee,” but this lower earnings limit was abolished during the first round of tendering in 1990. For both direct employees of the council and those employed by private sector firms, the restructuring of public sector manual employment has led to the growth of "a shifting mass of low-paid, insecure and often impoverished staff without employment rights or security” (Welch and Ellis, 1994, n.p.). Whilst Camden was committed to the provision of a high standard of public services for much of the post-war period (Goodwin et al., 1993), the borough's activities were curtailed through the 1980s and early 1990s both as a result of financial restrictions imposed by the former Conservative central government and because the effects of local socioeconomic restructuring placed increasing pressures upon local resources. 


\section{Competitive Tendering, Contracting out and the Local Labour Force}

When compulsory competitive tendering legislation first came into effect in late 1989, private sector firms had little success in winning contracts within any of the case study authorities. Variation of employment terms and conditions thus depended upon decisions taken by local councils’ Direct Service Organisations. Compared to the other two case study areas, workers in Camden remained slightly better off in hourly wage terms, although part-time working had increased, particularly within cleaning. By 1994, however, all three authorities had lost control of the majority of their cleaning and catering services to private firms. Not only did wages and terms and conditions become increasingly variable between the three authorities, but also there was a sharp trend towards the individualisation of employment contracts, as firms offered varying levels of remuneration to different workers.

It might have been expected that that the labour intensive nature of cleaning and catering work would sensitise contract service managers to the distinctive features of particular local labour markets. However, it turned out that managers in head offices often indicated that they did not necessarily give explicit consideration to local labour force characteristics prior to tendering for a contract: ${ }^{6}$

I'd like to say that we're very sophisticated... actually, the main factor is the labour [ie wage] rates in particular geographical areas (7 May 1994). ${ }^{7}$

Firms did make some attempt to gauge local wage rates for cleaning and catering work, in order to price their bid accordingly. A firm planning to bid for a contract advertised by Grampian Regional Council, for example, contacted the firm's local office in Aberdeen to determine local pay rates for private sector cleaners; another firm "asked all [their] cleaners if they had got any friends or relations who work in one of the other companies... what's the pay rate” (17 September 1993).

\footnotetext{
${ }^{6}$ Nine of eleven (82\%) head office managers suggested that the availability of a local labour force was not crucial to their bidding.

${ }^{7}$ At the same time, however, it might also be argued that wage rates do bear some relation to, and reflect, labour force characteristics.
} 
By contrast, managers were often inattentive-at least at the time the initial decision was made to bid for the contract — to the availability of local labour at that particular price. While the supply of labour is price-dependent in part, it is also shaped by the nature of the local labour force. Who will accept part-time working, where and during which particular hours, for example, all impinge on labour supply. The nature of household benefit arrangements will also structure the availability of labour. Cleaning and catering firms commonly assumed that DSO labour forces were “overmanned” [sic], and brelieved they would not need to recruit additional workers when they took over a contract. Although an existing labour force was already in place, incoming private-sector firms were not always able to retain the established labour force once a contract had changed hands. And nanagers also made assumptions about the ease with which they could in any case draw upon an easilytapped local workforce:

with schools and colleges, most of them are situated in places where there are people who are going to take their children there. [...] It might be that it's in a small village, but there's a certain amount of population there that one can draw on to do the work. (28 June 1994).

Nevertheless, for contract managers 'on the ground', staffing can pose problems: firms have had substantial difficulties in recruiting labour at the price they initially set in the contract. Even if firms are able to recruit sufficient staff, they may face problems of absenteeism and high levels of staff turnover during the contract period. In some cases, private companies have had to withdraw from contracts altogether. In others, councils have stepped in to renegotiate the terms of the contracts. One contract manager described an example of the latter situation-he had recently lost a large school cleaning contract with Berkshire County Council to a competing firm:

[...] let's take the Berkshire experience. Charters School, Sunningdale, or something like that. Virginia Water. There isn't a house in Virginia Water less than $£ 300,000$. There aren’t your Mrs. Mopps to come out cleaning. I mean, they're scouring the neighbourhood for someone to come in and clean their house. To whom they can pay cash, and will probably pick them up, take them back, they'll get little Johnny’s cast 
off clothes to take home to their kids, and it's a wonderful job. So you've got to go right the way up to somewhere like Bracknell to find cleaning staff. And [a competing firm] won that, at a price that was cheaper than mine, and they find (sarcastic tone) 'we can't get staff in the neighbourhood'. And to my utter amazement, they managed to get extra money out of Berkshire County Council for a bus... [...] I'd priced a bus in [to the contract]. Because I have been around a little bit, and I do know it, and I'm amazed that Berkshire [council]... I wouldn't have the temerity to go back, because it was a cock-up, you know, I think we put in something like $£ 4$ or $£ 5$ an hour, against a normal rate of maybe £3, plus transport, because you knew darn well you couldn’t get people... (17 September 1993).

This is an interesting account for two reasons. First, it indicates the 'messiness' of the tendering procedure: firms' involvement in CCT has not simply been a logical extension of capital into profitable new areas (Reimer, 1999b). Second, the Berkshire example highlights a division of labour within contract cleaning and catering firms. While managers at the national level are not centrally concerned with the availability of labour when they come to tender for a contract, managers at a local level must deal with the specificities of local labour forces. It is at this level, where the "dynamic dependencies" between employers and employees emerge, where “employers not only tap into distinctive local 'pools' of labour, but ... actively shape the communities in which they locate.” (Hanson and Pratt, 1995, 225).

\section{Firms shaping local labour markets: constructing geographies of employment}

Private sector cleaning and catering firms have become actively involved in the construction of particular local labour markets as compulsory competitive tendering has proceeded. By using specific recruitment strategies and through the ways in which firms organise labour utilisation, firms create locally-specific employment opportunities. Under the CCT legislation, local authorities’ own Direct Service Organisations (DSOs) must compete with private firms for the provision of services, and in this sense, they have been subjected to similar types of (commercial) pressures (see Painter, 1992). The position of DSOs is slightly different from that of private firms, however, in that DSOs are not allowed to bid for contracts outside the 
boundaries of their own local authority. ${ }^{8}$ While private firms can use profits made in one part of the country to cross-subsidise loss-making contracts in another, DSOs do not have such an option. Nonetheless, DSOs have found that they too have had to cut wages and terms and conditions of work in order to compete for contracts, and thus have also contributed to the increasing fragmentation of employment in much the same way as private firms.

Contractors made explicit assumptions about the workforce upon which they would be able to draw: they perceive that working in a school canteen is a job which is ideally suited to women with school-age children, for example. Cleaning work too, can be organised around domestic commitments. As one manager noted:

[...] it's a labour-intensive market, we draw a fair amount of our staff from local council estates. We probably draw a lot of our staff from other residential areas. You know, people do the job not because they're perhaps... a little less educated than somebody else who can go and get a job that's better paid, and better work... (pause) what's the word I'm looking for... job satisfaction, they also do these jobs because it suits them with family ties and family commitments and that sort of thing, you've got mothers looking after children, and commitments... and wives looking after husbands, and people looking after whoever... and their time slots for doing jobs are early mornings or evenings, because of their other commitments. So it suits them to come and do a part-time job. (18 February 1994).

There are a multiplicity of assumptions being made here - such as the (lack of) skills/training required to do cleaning work, and its appeal to the 'uneducated'. What is also evident, is the desire for a very local workforce. Thus, according to the manager of the civic catering contract in Camden, "ideally you would recruit everyone who’s local, because then you don't have problems with staff not turning up because their child is sick...” (5 August 1994). These sentiments are by no means straightforward: it is not clear why employees who live closer to work are less likely to be absent from work as a result of childcare 'problems'. However as Hanson and

\footnotetext{
8 There is some provision in the 1988 Local Government Act for authorities to become involved in crossboundary tendering, "but in a limited way," subject to the 1972 Local Government Act and the 1970 Goods and Services Act (Department of Environment, personal communication, 18 May 1995). During the time I was conducting research, it was generally assumed by local authority managers that cross-boundary tendering was unlawful; in any event most viewed such an idea as highly disloyal, given the pressure upon DSOs from private firms. See also Sparke (1993, Chapter 10).
} 
Pratt have argued, “employers' preferences and expectations about 'appropriate' home-work distances have been built into their hiring practices” (Hanson and Pratt, 1995, 163).

It is by focusing their recruitment upon very local areas that firms actively construct local labour markets. A cleaning manager described the ways in which his firm recruited a local labour force by distributing leaflets to residents of local council estates:

...[it's ] much cheaper than advertising in the paper, and you actually get it through people's doorways [...] 'cause one of the problems if you do advertise... recruiting... advertise in the Cambridge Evening News or whatever it is, and you want people in Long Road, you can either put down 'must be in Long Road area', but most people don't see that, they just see cleaners wanted, £3.50 and hour and that's it. And you'll get them ringing up from all over the place. Wasting our time, because they can't get there anyway. So we want people who are local who just walk straight into those jobs... (28 June 1994; emphasis mine)

Given that the city of Cambridge covers an area of little over 12 square miles, these are very local labour catchments indeed, formed not simply by the very real local transport constraints which workers face in the area, but also by the way in which employers' own assumptions about these constraints restricts the spaces over which they seek and hire labour.

Similarly, employers' perceptions about appropriate jobs for women with children influence their recruiting practices and recruitment spaces. The constraints upon women with domestic commitments mean that in the absence of affordable childcare they are often required to look for jobs close to home, and/or jobs which 'fit' around school hours. Fully cognisant of such domestic constraints, employers construct labour recruitment catchments from within these local residential areas.

Word-of-mouth recruitment by contract cleaning and catering firms is also important in the construction of local labour forces. As one cleaning manager commented:

...we do get a lot of people by, sort of asking the cleaners, you know, have you got a mother, sister, aunt, friend. And so you get a lot of referrals. Of course they're more reliable people when you get it 
through a referral. So we would prefer that form, if we can. (15 October 1993)

All of managers interviewed suggested that word-of-mouth recruitment was one of the first methods to which they turned to find workers, and one of the major catering contractors even operated a formalised bonus system, whereby workers receive a monetary reward for "recommend[ing] a friend" (6 October 1993). In this way, wordof-mouth recruitment also tends to reproduce particular gender divisions of labour, given the tendency for social networks to operate in gender-specific ways: as indeed the quotation above suggests. Here too, as Hanson and Pratt $(1995,173)$ argue, wordof-mouth recruitment "often yields a highly localised work force.”

However, word-of-mouth recruitment may not necessarily shape the labour market in such a way that the workforce is drawn from the local area. ${ }^{\mathbf{9}}$ There is evidence that, in some cases, the use of word-of-mouth recruitment by DSO managers operated to construct a non-local workforce. Many of the cleaning workers in Camden, for example, travelled from Southeast London to work in the borough. Contract managers suggested that this was not only a function of relatively high wage rates in the authority but because of strong familial and friendship-based connections between groups of workers. In Durham too, there were connections between the women who worked on the night-time cleaning shift in County Hall: groups of women travelled together from Chester-le-Street and from Langley Park, for example. In both London and to a slightly lesser extent, Durham, the availability of (reasonably) frequent public transportation enabled employees over quite large areas to take advantage of these word-of-mouth connections. Thus workforces are not always drawn from tightly circumscribed local catchments, although the Camden and Durham examples do illustrate the development of localised workforces.

The relevant question is whether a general trend towards the privatisation of local authority services will act to narrow opportunities for potential employees as a result of the different ways in which DSOs and private firms have tended to recruit

\footnotetext{
${ }^{9}$ Hanson and Pratt $(1995,173)$ do state that they had "found examples of established residential communities and workplaces that are spatially discontinuous," but they argue that employees in Worcester workplaces were more commonly drawn from local areas.
} 
workers. In County Durham the authority had long operated an explicit policy of providing jobs within the school meals service for women who had been widowed, and particularly for miners' widows. DSO managers also tended to use JobCentres as a key recruitment source. ${ }^{\mathbf{1 0}}$ Both of these strategies arguably will be less likely to construct a local workforce than the greater reliance on will word-of-mouth recruitment found within private sector contracters.

The temporal organisation of cleaning and catering work itself also acts to shape local labour market opportunities for women and men. Assumptions about the suitability not only of the type but also particular hours of work for women are paramount in employers' comments about their workforces. Thus as one private sector employers responded to a question about the length anfd timing of shifts:

Between... two to three hour shifts, generally. The other thing we try and avoid is also cleaning first thing in the morning as well. The only area of the country where it seems to work quite well is central London, where everybody does cleaning first thing in the morning. You very rarely have evening cleaning going on. In the rest of the country, it's all evening cleaning.[...] traditionally in London, people have gone out and gotten a two hour, three hour part-time job in the morning, and then gone to their full-time job. Out in the sticks, the women... to be quite honest with you... they will see to the breakfast, they'll see to the kids, they'll get the lunch ready for the kids, pack them up, and get them off to school. Well, that all happens between half past seven and 9:00 in the morning, so it really kills it as far as an early morning cleaning shift. Unless it's going to be say from 5:00 in the morning till 7:00, and there are very few premises that want that. So generally cleaning in the UK, except for London, is part-time in the evenings.

These presumptions about gendered working time feed through to the organisation of cleaning and catering work. The shift away from full-time working (alongside reductions to the hours worked by existing part-timers) has had an important effect upon local labour markets. Whilst much of the 'flexibility' literature suggests that employers' increasing use of 'non-standard' labour to perform cleaning and catering tasks stems from the fact that such work "requires a limited number of hours to

\footnotetext{
10 See also Rees and Fielder (1992, 362), who note that some private sector managers were "especially scathing” about JobCentres.
} 
complete” (McGregor and Sproull, 1992, 226), there is no clear reason for all cleaning and catering work to be part-time. Prior to CCT, many cleaning and catering jobs were in fact full-time, and 'continental' shifts are commonly used in the cleaning of public places, such as airports or bus stations. Local authority cooks in County Durham commonly worked 35 hours a week, and a significant proportion of cleaning work in Camden was organised on a full-time basis (see also Hunter and McInnes, 1991).

However part-time working clearly provides financial advantages to employers, particularly if employees' earnings (and therefore hours) are kept below the National Insurance threshold (£55 per week in 1994). ${ }^{\mathbf{1 1}}$ There is evidence that employers have been only too aware of the intersection between employment and benefit arrangements, and have deliberately kept hours of work low. ${ }^{12}$ One result has been that the shift to greater part-time working appears to have altered the gender complexion of the workforce. As two DSO managers in Camden commented:

the interesting thing is there used to be a lot of men in the service, a lot of the full-timers were men, and the part-timers were women. And although, you know, a fair proportion of women were working fulltime as well. The service now is largely female... (23 May 1994).

While this highlights an underlying belief that part-time working will be unattractive to men because it will not provide a 'breadwinner' wage, there are also implications for the nature of women's employment locally. One common response of women in these contracted-out local authority services to reductions in hours of work and wages has been to take on second and even third jobs (Reimer, 1999a). Thus CCT has contributed strongly to the fragmentation of employment and the expansion of multiple jobholding. But not only have private contracters’ preference for part-time

\footnotetext{
11 A 1994 House of Lords decision declared that part-time workers must be given the same redundancy and unfair dismissal rights as full-time employees. (Guardian, 1994). However, there are still certain statutory rights, such as medical suspension pay, and time off for union duties, to which workers employed less than 16 hours a week are not entitled (Labour Research, 1994) Further, part-time employees are frequently excluded from sick pay and unemployment benefits by virtue of the low wages which commonly characterise part-time working.

12 See also Leonard (1998). Of those employees in the CCT study who were married or living with a partner, fifteen percent had a partner in receipt of benefit (unemployment, invalidity or state pension).
} 
workers served to fragment work processes and job opportunities, their word-ofmouth recruitment policies have also encouraged multiple jobholding:

around London, when we're starting up a new contract, the existing staff have got friends, that they know want jobs. Or if we're starting up an evening cleaning contract, we'll go to our morning cleaning contracts, and see what ladies or blokes there want to do an evening job as well. So if they get two and a half hours in the morning, they might be looking for a two and a half hour evening job, to increase their income. So you get staff that way. (19 October 1993).

If the recruitment practices under privatisation have restructured the working lives of the affected workforce, the nature of the local labour market has also modified the prcatices of the forms themselves as the following account shows.

\section{Impacts of local labour markets upon firms}

Although managers in head offices suggested that the nature of local labour markets did not directly influence initial tendering decisions, the ease or difficulty with which firms are able to engage staff in particular places has clearly been dependent upon the characeristics of the local labour market. For example, managers often suggested that they had experienced difficulties in recruiting contract claening or catering staff in upper middle-class residential areas:

SR: do you ever have-when you take on a contract—have difficulties recruiting labour?

YL: um... generally no, but, if you take on the obscure locations in... let's say down in Berkshire, it's difficult to ... like Wantage, or Lambourne, and you've got a very limited market in which you can't get anybody to do any cleaning... (19 October 1993)

In a rather different context, other firms have experiened difficulties recruiting staff in remote rural locations. In some remote Fenland villages in Cambridgeshire, for example, the county Direct Service Organisation had to pay up to a twenty percent bonus to the basic hourly wage for cleaning and catering staff. And in some cases such problems operate at remarkably local scales, as illustrated by a cook in a large Durham Sixth Form College: 
This is a hard kitchen, because it's in the middle of nowhere, and you can't get anyone to work. It's all private houses; university people, and those women don't want to come and work here. So often you can't get anyone; Gilesgate Estates are too far away, what with bus fare (7 October 1994).

The labour geography that the cook constructs here is an interesting one: although the school is only a few minutes' walk from the centre of Durham, she suggests that it is "in the middle of nowhere" in terms of finding staff to work in the kitchen.

Local unemployment rates have a substantial effect upon firms' ability to recruit staff. A cleaning manager noted that

the areas of high unemployment, it's easier for us to get staff. [...] so we have problems in some areas and not in others. The recession has changed that a bit. It's much easier to get staff now than it was three years ago. Three years ago we couldn't get staff in Guildford, or Bracknell, or Basingstoke, or Reading. We just couldn't get them. I mean, we went from-we're probably paying $£ 3.50$ an hour there now-we were paying $£ 4.50$ an hour three years ago; we couldn't get the people. They weren't there to do the cleaning jobs (15 October 1993; emphasis in original).

Further, if, as one manager argued, "the factory up the road [had] just closed", employees would be less resistant to contractors' efforts to lower wage rates. A Cambridgeshire personnel manager noted, for example, that even when wage rates were cut considerably in the second round of building cleaning tendering, many staff stayed on.

We were quite pleased that sort of over $90 \%$ of people agreed to the new terms. So we didn't have a massive problem of people saying, well, you can keep your contract, we don't want it. We're going to go and do something else. Which I think is a reflection of the state of the economy, people didn't have much of a choice (2 June 1994).

The effects of local unemployment levels are different in different parts of the country: a contractor in the Northeast suggested that the relationship between unemployment rates and his ability to recruit workers was the opposite to that which the Southeast manager had described:

we find difficulty in a market like Cleveland, where there's a very high unemployment rate, and therefore ladies don't want a job, because it affects whatever benefits they get in the family. So we find a greater difficulty where there's high unemployment. [...] So where there's low 
unemployment, we tend not to have a problem, because the people who we take on are genuinely looking just for pin money rather than family living money. (22 September 1994).

Firms' ability to recruit staff is not simply a function of general unemployment levels in a particular place, however, but is also related to the availability of other types of similar work. The fact that a sizeable number of cleaning and catering jobs in Cambridge and Durham are to be found within the university sector is an important feature of the labour market within these two urban areas. Contract firms are less able to drive wages down in places where potential staff have more opportunities for paid employment. Indeed, buoyant local labour market conditions can force contract managers to increase wages:

cleaners in Cambridge tend to leave you for no reason at all. They just disappear. I think when... [...]. when we were having problems with labour in East Anglia, that we as an industry tended to throw money at the problem, and the labour rates in Cambridge went up higher than they did in London, and we had two particular areas, one was East Anglia, and one was Crawley, around Gatwick Airport, where the wage rates for cleaners were, for a time, certainly for 18 months/two years, higher than they were in London. So the cleaners were going for the highest bidder. (27 April 1994).

Interviews with workers confirmed the frequency with which cleaning and catering workers would move in and out of different jobs as pay rates changed.

Contractors suggested that they also competed for staff with households employing waged domestic labour:

[...] once you're in those rural areas, there are people that do cleaning, but they'll probably be doing the cleaning for private houses, big places down there, you know, and those people are probably getting it tax free, maybe £4, £5 an hour. So we've got to compete in that marketplace. So you would expect me, or I always expect, in those areas, to pay a much higher rate of pay than ever I would in central London. You know, in fact, down in Lambourn, and Wantage, that area, we pay $£ 4.25$ an hour, to $£ 4.50$ an hour. In Westminster, I pay $£ 2.80$ an hour. I've got plenty of cleaners in Westminster, but I haven’t got so many down there, at £4.50. (19 October 1993)

The manager drew a contrast between central London and the Home Counties, but it is also possible to consider a North/South dimension to the competition firms face from households employing cleaning staff. In this regard, Gregson and Lowe's 
(1994) study of domestic cleaning labour provides an interesting comparison: they observed that households in the Southeast had more difficulty finding cleaning staff than did those households they interviewed in the Northeast., and they argue that this has much to do with contrasting local labour market conditions within the two regions:

In the case of the north-east, we would anticipate that two factors proved particularly important in ensuring the ready availability of waged domestic labour, namely the type of 'female' employment generally available within the region, and the high levels of male unemployment through the 1980s. In contrast, in the booming south of the 1980s, with jobs relatively easy to come by (particularly within the service sector) and low levels of male unemployment, the alternatives to waged domestic work would almost certainly have appeared more attractive (Gregson and Lowe, 1994, 300, fn 2).

Finally, cleaning and catering firms also compete for labour with firms outside these two sectors. Several managers suggested that the (part-time) hours of work that they offered put them in direct competition with, for example, supermarkets: “[...] when job sharing in supermarkets first came on to the scene, we lost a lot of staff to ... doing the checkout in a shopping mall” (13 October 1993). Another contractor stated that recruitment had become "more and more difficult" as supermarkets

[...] started taking on shelf-fillers, in the hours that our part-time labour traditionally could come out to work. You know, when the husband had come in, kids had come home from school, so between 5:30, let's say, and 8:00, which is the time we traditionally clean. Supermarkets were offering the same work...(27 April 1994)

In places where local authority employment had in the past been relatively well paid in comparison with other jobs, the contracting-out of cleaning and catering workand the accompanying cuts in wages and terms and conditions-may have made other work seem more attractive. A cleaning manager with contracts in Cambridgeshire noted that

... if a cleaner had been working for the local authority for a long time, and suddenly because of legislation it went out to... it was outsourced, many of the girls said well, look, this is a good time to get out of cleaning altogether, and leave it, and either go into supermarkets, or go 
into banks, or take a course somewhere, and go into administration part-time... There was a glut of part-time jobs coming ... into the employment. (27 April 1994).

\section{Some Implications for Conceptualising Local Labour Markets}

The complex processes of labour market transformation outlined in this chapter have a number of important implications for the conceptualisation of local labour markets. It should be clear from the preceding discussion that my approach to labour markets is far removed from "the idealised, equilibrating world of the orthodox economist's demand-and-supply schedules” (Peck, 1996, p. 262). I have sought to demonstrate how employers and employees interact within particular local labour market contexts, emphasising their fluid construction through (for example) employers' recruitment activities or their presumptions about gendered working times. Further, however, I have pointed to the difficulties which emerge from a conceptualisation of local labour markets which has its origins in segmentation theory. Two key issues emerge.

The first has to do with the way in which we think about local labour market processes. On this issue Peck has rightly critiqued segmentation theory for its implicit focus on the national scale, arguing that segmentation occurs at local levels as well (Peck, 1996). However, the primacy of general processes still remains in Peck's analysis, in as much that the importance of the local appears to be as an arena within which "common underlying dynamics" take on different specific forms: "General processes have socially, institutionally and geographically variable outcomes” (ibid. p. 266). This view does not rest easily with the case study material presented here, which has emphasised the ways in which contract service firms work within and through local employment geographies as they bid for contracts, recruit staff, and compete for labour. The configuration of the local labour market, particularly the way it is organised spatially, is shaped at this level. Only in the most general terms can these features be "built down” (ibid, p.102) from nationwide economic conditions 
and national regulatory processes, or local outcomes be 'read off' from general theories.

The second issue concerns the way in which local labour markets are being transformed in an era of fragmented and disorganised work (see also Reimer 1999a). The extent to which private sector firms and Direct Service Organisations have been actively involved in constructing fragmented work schedules for individual workers and developing highly uneven wage hierarchies demonstrates that the lines of division between and among employees in local labour markets are much more complex and shifting than segmented labour market theory dichotomies like 'primary' and 'secondary' might suggest. Under compulsory competitive tendering, deteriorating work conditions have by no means been equally experienced by all workers, nor have they neatly fractured along gender lines. Further, features such as the emergence of multiple jobholding render existing local labour market concepts, such as the notion of "place-specific social networks" (Hanson and Pratt, 1995, p. 225), more problematic than is usually recognised. The fragementation of the work week into a number of separate jobs and/or time slots with the same or different employers may actually give workers access to a more extensive range of social networks than those working through a standard work week or in a single location. At the same time, the tightly scheduled lives of multiple jobholders may constrain the type and range of occupational choices available to employees. Local labour market dynamics are now significantly more complicated than they were during an (albeit brief) era of full-time, continuous and stable employment. However these are not just empirical complexities: they are theoretical ones too.

Acknowledgements: Research on compulsory competitive tendering was funded by a Social Sciences and Humanities Research Council of Canada Doctoral Fellowship (Award No. 752-94-0045). Many thanks also to Ron Martin and Philip Morrison for their helpful editorial comments. 


\section{References}

Clark, Gordon 1987 “Job search theory and indeterminate information,” in Regional labour markets Ed. Manfred Fischer and Peter Nijinkamp North Holland, Elsevier, pp. 169-188.

Coe, Neil 2000 “On location: American capital and the local labour market in the Vancouver film industry” International Journal of Urban and Regional Research 24 79-94.

Cooke, Philip 1983 “Labour market discontinuity and spatial development” Progress in Human Geography 7 543-565.

Coombes, M.G., A.E. Green and D.W. Owen, 1985 “Local labour market areas for different social groups” Discussion Paper No. 74, Centre for Urban and Regional Development Studies.

Crang, Phil and Ron Martin, 1991 “Mrs. Thatcher's vision of the 'new Britain’ and the other sides of the Cambridge phenomenon” Environment and Planning D: Society and Space 9 91-116

Fischer, Manfred and Peter Nijinkamp, 1987 “Labour market theories: perspectives, problems and policy implications,” in Regional labour markets Ed. Manfred Fischer and Peter Nijinkamp North Holland, Elsevier, pp. 37-52.

Goodwin, Mark, Simon Duncan and Susan Halford, S. 1993 Regulation theory, the local state, and the transition of urban politics Environment and Planning D: Society and Space 11 67-88.

Gregson, Nicky and Michelle Lowe, 1994 Servicing the middle classes: class, gender and waged domestic labour in contemporary Britain London, Routledge. 
The Guardian, 1994 "Women gain most from Lords ruling,” 4 March 1994.

Hanson, Susan and Geraldine Pratt, 1995 Gender, work and space London, Routledge.

Hubbuck, Jim and Mike Coombes, 1989 “1991 Census: local labour market areas for socio-economic and racial minority groups” Discussion Paper No. 92, Centre for Urban and Regional Development Studies.

Hudson, Ray 1989. Labour-market changes and new forms of work in old industrial regions: Maybe flexibility for some but not flexible accumulation. Environment and Planning D: Society and Space 7: 5-30.

Hudson, Ray Susannah Schech and L. Krosgaard Hansen, 1992. Jobs for the girls? the new private sector service economy of Derwentside district. Occasional publications, no. 28. Durham: Department of Geography, University of Durham.

Hunter, Laurie and John MacInnes, 1991 “Employers’ labour use strategies: case studies” Employment Department Research Paper No. 87).

Labour Research, 1994b “Do part-time workers have equal rights?” July, pp. 8-10.

Leonard, Madeline 1998 “The long-term unemployed, informal economic activity and the 'underclass' in Belfast: rejecting or reinstating the work ethic" International Journal of Urban and Regional Research 22 42-59.

Martin, Ron 1986 “Getting the labour market into geographical perspective” Environment and Planning A 18 569-572.

Martin, Ron, forthcoming “Local labour markets: their nature, performance and regulation,” in Handbook of economic geography Ed. Gordon Clark, Meric Gertler and M. Feldman, forthcoming. 
McDowell, Linda and Doreen Massey, 1984. A women’s place? In Geography matters: a reader, ed. D. Massey and J. Allen, 128-147. Cambridge: Cambridge University Press.

McGregor, Alan and Alan Sproull, 1992 "Employers and the flexible workforce” Employment Gazette, May, pp. 225-234.

Mingione, Enzo 1991 Fragmented societies: a sociology of economic life beyond the market paradigm Trans. Paul Goodrick Oxford, Blackwell.

Morrison, Philip 1990 “Segmentation theory applied to local, regional and spatial labour markets” Progress in Human Geography 14 488-528

Office of Population Censuses and Surveys, 1991. Census 1991 London, HMSO.

Painter, Joe 1992 “The culture of competition” Public Policy and Administration 7 58-68.

Peck, Jamie 1989a “Reconceptualising the local labour market: space, segmentation and the state” Progress in Human Geography 13 42-61.

Peck, Jamie 1989b "Labour market segmentation theory" Labour and Industry 2 119-144.

Peck, Jamie 1992 “Labour and agglomeration: control and flexibility in local labour markets” Economic Geography 68 325-347.

Peck, Jamie 1996 Work-place: the social regulation of labour markets London, Guildford.

Pinch, Steven 1987 “Labour-market theory, quantification and policy” Environment and Planning A 19 1477-1494.

Pratt, Geraldine 1999 “From Registered Nurse to Registered Nanny: discursive geographies of Filipina domestic workers in Vancouver, B.C.” Economic Geography 75 215-236. 
Rees, Gareth and Sarah Fielder, 1992 “The services economy: subcontracting and the new employment relations: contract catering and cleaning” Work, Employment and Society 6 347-368.

Reimer, Suzanne 1997 Geographies of fragmentation: the restructuring of employment in public sector services Unpub. $\mathrm{PhD}$ thesis, Department of Geography, University of Cambridge.

Reimer, Suzanne 1998 “Working in a risk society” Transactions, Institute of British Geographers 23 116-127.

Reimer, Suzanne 1999a “ 'Getting by’ in time and space: fragmented work in local authorities” Economic Geography 75 157-177.

Reimer, Suzanne 1999b “Contract service firms in local authorities: evolving geographies of activity” Regional Studies 33 121-130.

Sassen, Saskia 1991 The global city: New York, London, Tokyo Princeton, Princeton University Press.

Segal Quince and Partners, 1985 The Cambridge phenomenon: the growth of high technology in a university town. Segal Quince and Partners, Mount Pleasant House, Mount Pleasant, Cambridge.

Sparke, Andrew 1993 The compulsory competitive tendering guide Butterworths, London.

Welch, Caroline and Dave Ellis, 1994 Public service, private hardship Report by the Low Pay Unit for Greater London Unison, n.p. 